\title{
Of Rebels and Disobedients: Reflections on Arendt, Race, Lawbreaking
}

\author{
Ayça Çubukçu' ${ }^{10}$
}

Published online: 15 July 2020

(C) The Author(s) 2020

\begin{abstract}
Hannah Arendt valued the unprecedented, the unexpected, and the new, yet in essays crafted at the end of the rebellious 1960s, struggled to square this valuation with a palpable desire for law and order. She lamented that criminality had overtaken American life, accused the police of not arresting enough criminals, and charged 'the Negro community' with standing behind what she named black violence. At once, she praised 'the white rebels' of the student movement in the United States for their courageous acts of disobedience. This essay explores how differential Arendt's treatment of lawbreaking action was in an effort to understand how 'certain sections of the population' in the United States could appear to stand for criminality rather than civil disobedience to her mind. It examines how Arendt's reflections on the ostensibly non-racial subjects of civil disobedience and lawbreaking were underwritten by racial, when not racist, ways of thinking. The essay also raises a larger question: to the extent that the concept of civil disobedience involves limits, how are those limits drawn to the exclusion of certain kinds of actors and their particular claims in the public realm? Pondering this question through Arendt, it concludes that in her theorization of civil disobedience, Arendt was profoundly limited by the fabulous tale that the United States is an exceptional land of freedom and democracy in the world.
\end{abstract}

Keywords Hannah Arendt · Civil disobedience $\cdot$ Lawbreaking $\cdot$ Race $\cdot$ Racism . Violence

Ayça Çubukçu

a.cubukcu@1se.ac.uk

1 London School of Economics and Political Science, London, UK 
Hannah Arendt was conservative in more ways than one. ${ }^{1}$ She valued the unprecedented, the unexpected, and the new, ${ }^{2}$ yet in 'Civil Disobedience' and other essays crafted at the end of the rebellious 1960s, struggled to square this valuation with a palpable desire for law and order. She lamented that criminality had overtaken American life, accused the police of not arresting enough criminals (Arendt 1970, pp. 70-74), and charged 'the Negro community' with standing behind what she named black violence (Arendt 1969, p. 19). At once, she praised 'the white rebels' of the student movement in the United States for their courageous acts of disobedience. In what follows, my aim is to explore how differential Arendt's treatment of lawbreaking action was. ${ }^{3}$ This will require engagement with the conceptual distinctions she proposed-distinctions between power and violence, civil and criminal, politics and morality, opinion and interest-in an effort to understand how "certain sections of the population' in the United States could appear to stand, to her mind, for criminality rather than civil disobedience.

While the importance of Arendt as 'one of the seminal thinkers of the twentieth century' is now well established, ${ }^{4}$ she has even acquired 'saintly status' ${ }^{5}$ in some scholarly milieux, especially in the United States. Nonetheless, groundbreaking scholarship culminating with Hannah Arendt and the Negro Question, published in 2014 by the philosopher Kathryn T. Gines, has provided a 'systematic analysis of anti-Black racism in Arendt's work' ${ }^{6}$ Focusing on a subject only cursorily explored

\footnotetext{
${ }^{1}$ Many scholars concur with Maurizio Passerin d'Entrèves (1994, p. 1) that Arendt 'cannot be characterized in terms of the traditional categories of liberalism, conservatism and socialism'. Nevertheless, James Martel (2011, pp. 143-157) has studied Arendt as an anarchist thinker. While I agree with Hutchings (2017, p. 33) that one of the most remarkable things about Arendt's work is 'its capacity to unsettle comfort zones of ideological right/left thinking and the impossibility of incorporating it under any particular "ism"', in this essay, I am interested in exploring Arendt's (1970, p. 89) conservative tendencies (rather than Arendt as $a$ conservative) in the context of the United States in the late 1960s, which she characterized as a 'revolutionary situation'. I will return to this point in part III of this essay. Although limitations of space disallow a discussion, the wider historical context of the period under consideration is the Cold War and 'the iconic year 1968', which 'marks the 1960s as a global moment' (Marotti 2009, p. 97). For a careful reading of Arendt and her conceptualization of 'totalitarianism' in the context of the Cold War, see Losurdo (2004, pp. 25-255). I thank Sebastian Budgen for this reference.

${ }^{2}$ For an examination of the constitutive role of 'the unprecedented' in Arendt, see Çubukçu (2015, pp. 684-704). For an analysis of 'the politics of the extraordinary' in Arendt's thought in relation to the perplexities of revolution, constitution making, action, and freedom, see Kalyvas (2008, pp. 70-74).

${ }^{3}$ I reflect on the problem of lawbreaking in the case of Arendt's Eichmann in Jerusalem: A Report on the Banality of Evil (1994) in another essay, Çubukçu (2015).

${ }^{4}$ See Passerin d'Entrèves (2019). Craig Calhoun and John McGowan offer an informative narrative of what was once Arendt's wavering prominence in the US academy, from the 1950s through 1996. See Calhoun and McGowan (1997). In contrast, note how an endorsement for John McGowan's book, Hannah Arendt: An Introduction (1998) already declares in 1998 that the book is a welcome addition to 'the growth industry known as Arendt studies'. For my earlier contributions to this 'industry', see Çubukçu $(2015,2017)$.

${ }_{6}^{5}$ I thank Nathaniel Berman for this formulation.

${ }^{6}$ See the publisher's summary of Gines (2014), Hannah Arendt and the Negro Question on the back cover of the book and on its website. For earlier work exploring anti-Black themes in Arendt which later scholarship built on, see Dossa (1980, pp. 309-323) and Norton (1995, pp. 247-262).
} 
by Gines, ${ }^{7}$ I aim here to contribute to critical studies of Arendt's thought by offering an interpretation of this profound yet problematic thinker's reflections on civil disobedience in the late 1960s. Like Gines, 'I am not attempting to dismiss Arendt's thought altogether and label her a racist' (2014, p. 91). That, to my mind, would be less fruitful an endeavour than attempting to understand how Arendt's reflections on the ostensibly non-racial subjects of civil disobedience and lawbreaking were underwritten by racial, when not racist-depending on one's interpretation of this concept $^{8}$ — ways of thinking. If, as recently as 2018, a conference on 'Citizenship and Civil Disobedience' held at the Hannah Arendt Center in the United States can be introduced at length without observing how Arendt categorically excluded certain citizens, particularly the Black Power movement, from the zone of civil disobedience, this may still prove worthwhile an effort (see Berkowitz 2018).

On the other hand, I raise in this essay a larger question: to the extent that the concept of civil disobedience involves limits (imposed, among others, by the requirement of 'civility' and the presumption that a given state is fundamentally just), how are those limits drawn to the exclusion of certain kinds of actors and their particular claims in the public realm? ${ }^{9}$ Pondering this question through Arendt, instead of concluding that she was 'one of the most prescient observers of America' (Berkowitz 2018) or the phenomenon of civil disobedience, we may learn from the ways in which she was profoundly limited-despite warnings offered by her contemporaries $^{10}$ - by the fabulous tale that the United States is an exceptional land of freedom and democracy in the world. In the end, it was political actors, racialized political actors, whose lawbreaking action challenged the foundational tales of American exceptionalism, whom Arendt barred from the category of civil disobedience.

\footnotetext{
7 Unfortunately, Gines (2014, pp. 120-122) considers Arendt's 'Civil Disobedience' very briefly.

8 While examining the immense debate about what racism does and does not entail is beyond the scope of this essay, considering Arendt, I will return to this question in part III. For an effort to develop 'philosophical methodologies for (re)conceptualizing race and racism' beyond the black/white binary in the context of the United States, see Critical Philosophy of Race (2013). For a revealing survey of '(white) Western intellectuals', particularly Arendt's contemporaries from Germany, which historically situatesif not excuses-Arendt's views on 'race and culture', see King (2010, pp. 113-134).

9 I thank both Partha Chatterjee and Tobias Kelly for teasing out this question in their comments on an earlier version of essay. See Kelly's (Thiranagama et al. 2018) co-authored piece on 'civility' for a critical, anthropological approach to this concept and its operations. For a contemporary 'defense of uncivil disobedience', even in 'supposedly legitimate, liberal democratic states', see Delmas (2018), particularly chapter two.

10 For a review of 'the opportunities Arendt had to engage with Black intellectuals about the Negro question', see Gines (2014, pp. 3-7). For an account of Arendt's exchange with James Baldwin, see Caver (2019, pp. 35-61). For an exclusive focus on Arendt's German contemporaries, 'who spoke of racial and crosscultural matters in ways remarkably similar to, or even more ethnocentric than Arendt', see King (2010, p. 114).
} 
When introducing 'Civil Disobedience' in 1970, published in her anthology Crises of the Republic, Arendt raised three matters in a single breath. First was 'the disastrous increase in crime in the streets'; second, the undermining of 'any simple faith in the central importance of fidelity to law'; and third 'ample evidence that skilfully organized campaigns of civil disobedience can be very effective in securing desirable changes in the law' (Arendt 1970, p. 51) ${ }^{11}$ All three matters involved lawbreaking, or 'disobedience to the law' in her parlance (Arendt 1970, p. 51). Although Arendt brought up these matters as possible explanations for the cry of despair she heard in the primary question-'Is the law dead?'-then occupying jurists of New York City's Bar Association (Arendt 1970, p. 51), the central concern of her essay was arguably another. How, if at all, could disobedience to the law be justified? In particular, at stake in 'Civil Disobedience' was the justifiability, if any, of lawbreaking action in 'a society of consent' such as is the United States ostensibly (Arendt 1970, p. 51).

In response to this problem, Arendt appraised, and rejected, various justifications developed in the 1960s by jurists sympathetic to civil disobedience in order to solve the chief difficulty they faced-namely, that 'the law cannot justify the breaking of the law' (Arendt 1970, p. 53). ${ }^{12}$ Some of these jurists had attempted to address this difficulty by asserting the compatibility of civil disobedience with the duality of American law (Arendt 1970, p. 53). These jurisprudential attempts were refuted 'on factual grounds', Arendt found, when 'the civil disobedients of the civil-rights movement smoothly developed into the resisters of the antiwar movement who clearly disobeyed federal law' (Arendt 1970, p. 53). Now, by appeals to a 'higher law', the disobedients were challenging not only particular state laws but also federal law, and jurists who had conveniently identified this 'higher law' with the U.S. constitution were thrown back to ground zero. How then was the line between 'common criminals' and 'civil disobedients' to be drawn when, in a period of crisis, the very distinction between the two- a distinction Arendt was thoroughly invested in maintaining — had become 'more fragile' in character (Arendt 1970, p. 55)?

Arendt found that the 'confusion, polarization and growing bitterness' of debates around these questions were partly caused by a theoretical failure to understand 'the true character of the phenomenon' (Arendt 1970, p. 55).

Whenever the jurists attempt to justify the civil disobedient on moral and legal grounds, they construe his case in the image of either the conscientious objector or the man who tests the constitutionality of a statute. The trouble is that the situation of the civil disobedient bears no analogy to either for the simple

\footnotetext{
${ }_{11}$ Arendt took the last two quotations directly from Hughes (1968), 'Civil Disobedience and the Political Question Doctrine'.

${ }^{12}$ Arendt quotes Carl Cohen here and uses this quotation multiple times in 'Civil Disobedience'. Partly because 'the law cannot justify the breaking of the law', she explicitly proposes a political approach to the problem of civil disobedience.
} 
reason that he never exists as a single individual; he can function and survive only as a member of a group. (Arendt 1970, p. 55)

Thus, Arendt insisted, one of the chief characteristics of civil disobedience was that it presupposed group action. She thought the Freedom Riders ${ }^{13}$ of the American civil rights movement was a paradigmatic case of civil disobedience, for these activists could only enact 'indirect disobedience' by collectively violating laws, of traffic for instance, that they regarded as 'nonobjectionable in themselves in order to protest unjust ordinances or governmental policies and executive orders' (Arendt 1970, p. 56). It was 'precisely this indirect disobedience', Arendt further found, 'which would make no sense whatsoever in the case of the conscientious objector or the man who breaks a specific law to test its constitutionality, that seems legally unjustifiable' (1970, p. 56).

This seeming legal unjustifiability was to lend credence to the need Arendt would immediately assert to distinguish between conscientious objection and civil disobedience:

Hence, we must distinguish between conscientious objectors and civil disobedients. The latter are in fact organized minorities, bound together by common opinion, rather than by common interest, and the decision to take a stand against the government's policies even if they have reason to assume that these policies are backed by a majority; their concerted action springs from an agreement with each other, and it is this agreement that lends credence and conviction to their opinion, no matter how they may have originally arrived at it. (Arendt, 1970, pp. 56-57)

The constitutive contrast between 'common opinion' and 'common interest' in this passage is not incidental as it reflects a web of conceptual distinctions that Arendt developed in other writings around 1968, including 'Truth and Politics' and On Violence. ${ }^{14}$ In Arendt's judgement, while opinions could be 'impartial' and generalizable through persuasion and agreement among those acting in concert, interests were 'subjective' and particular, even if they too could be shared among members of a group. Opinions, for Arendt, were (to be) formed in disinterested a fashion, where disinterestedness was to be understood and practiced as 'the liberation from one's own private interests' (Arendt 1993a, p. 242). 'Interests' were unpolitical to the extent that, like conscience, they concerned 'man in his singularity' (Arendt 1993a, p. 246) and not man as a citizen, 'an acting being concerned with the world and the public welfare rather than his own well-being' (Arendt 1993a, p. 245). Man qua citizen, aiming for the 'common good', would (have to) form his opinion impartially, free 'from the private interests that make it blind, from the subjective illusions that entrap it'. 15

\footnotetext{
${ }^{13}$ The Freedom Riders of the American civil rights movement challenged racial segregation in public buses by riding them in the South in mixed racial groups. See Raymond Arsenault (2006).

${ }^{14}$ For a review of Arendt's understanding of 'opinion' in relation to 'politics', see Enaudeau and Bonnigal-Katz (2007).

${ }^{15}$ For a review, see Enaudeau and Bonnigal-Katz (2007).
} 
Disinterestedness, Arendt declared in her essay 'Crisis in Culture' from the early 1960s, meant that 'neither the life interests of the individual nor the moral interests of the self are involved' (Arendt 1993a, p. 222). Even if such non-involvement were possible in the first place, however, what would then remain of the individual-and her capacity to judge - after the withdrawal from relevance of the 'life interests' and the 'moral interests' of herself? In any case, calling disinterestedness 'impartiality', by 1968, Arendt would define it as the 'freedom from self-interest in thought and judgment' (Arendt 1993b, p. 262), positioning it as 'the root of so-called objectivity, this curious passion unknown outside Western civilization, for intellectual integrity at any price' (Arendt 1993b, p. 263). It was only in Western civilisation, then, where one could know how to form, for the achievement of the common good, 'objective' opinions free from private interest and the moral interests of the self.

Equating opinion formation with political thought itself and asserting that its hallmark was its 'representative' character, Arendt averred: 'The very process of opinion formation is determined by those in whose places somebody thinks and uses his own mind, and the only condition for this exertion of the imagination is disinterestedness, the liberation from one's own private interests' (Arendt 1993b, pp. 241-242). But even in Western civilization, where such a Kantian 'enlarged mentality' could take hold, Arendt knew:

Of course, I can refuse to do this and form an opinion that takes only my interests, or the interests of the group to which I belong, into account; nothing, indeed, is more common, even among highly sophisticated people, than the blind obstinacy that becomes manifest in lack of imagination and failure to judge. But the very quality of an opinion, as of a judgment, depends upon the degree of its impartiality. (Arendt 1993b, p. 242)

Thus, Arendt would position 'impartiality' as the criteria for judging the quality of an opinion in 'the market place where opinion stands against opinion' (Arendt 1993 b, p. 244). There in the market place, if the disinterested formation of impartial opinions commonly failed, then 'blind obstinacy', a stubborn refusal to be persuaded would have taken hold, making evident a 'lack of imagination and failure to judge', as if imagination and judgement as such would require the successful generalization of an impartial opinion.

Besides her civilizational criteria for achieving impartiality, On Violencepenned in 1969 shortly before 'Civil Disobedience' and shortly after 'Truth and Politics' - demonstrates Arendt's racial, if not outright racist, disdain for 'interest groups' who, in the context of the rebellious 1960s, acted on particular self-serving interests instead of partaking in the disinterested creation of a common opinion. In a notorious passage of this text, Arendt wrote:

Serious violence entered the scene [of the student movement in 1960s] only with the appearance of the Black Power movement on the campuses. Negro students, the majority of them admitted without academic qualification, regarded and organized themselves as an interest group, the representatives of the black community. Their interest was to lower academic standards. (Arendt 1969, p. 18) 
Arendt protested further that rather than 'the disinterested and usually highly moral claims of the white rebels', the academic establishment tended to yield more to 'Negro demands, even if they [were] clearly silly and outrageous' (Arendt 1969, p. 19). In a revealing appendix to her racialized juxtaposition of the disinterested claims of 'the white rebels' with the self-interested demands of 'the Negro students', Arendt would forcefully assert that 'Bayard Rustin, the Negro civil-rights leader, has said all there is to be said on this matter': 'black students were "suffering from the shock of integration" and looking for "an easy way out of their problems"; what Negro students need[ed] [was] "remedial training" so that they "can do mathematics and write a correct sentence", not "soul courses" about-in Arendt's words'African literature, and other non-existent subjects' (Arendt 1969, Appendix VIII to p. 19 , n. 32 on p. 96). It is not irrelevant to observe here that Bayard Rustin, who courageously talked 'common sense' according to Arendt (1969, Appendix VII to p. 19 , n. 32 on p. 96) became a neo-conservative by the end of his life (see Creegan 2016).

Arendt's constitutive, racialized contrast between the disinterestedness of the white rebels and the self-interestedness of the Black Power movement was intimately tied to her critique of violence. ${ }^{16}$ Whereas the former group stood for "nonviolent "participatory democracy" and sought to build power, what the Black Power movement offered was, according to Arendt, 'interests plus violence' (Arendt 1969, p. 19). Further, the interests of the Black Power movement-conveniently excluded from the racially unmarked categories of 'the students' and 'the student movement' by Arendt-included 'an ideological commitment to the non-existent "Unity of the Third World", which revealed, to her mind, 'an obvious interest in a black-white dichotomy ... an escape into a dream world in which Negroes would constitute an overwhelming majority of the world's population' (Arendt 1969, footnote 37, pp. 21-22). The case was different with 'the students', she found, who, 'caught between the two superpowers and equally disillusioned by East and West', pursued a third ideology 'inevitably' (Arendt 1969, footnote 37, p. 21).

Arendt assessed the student movement along with the New Left as a global phenomenon of rebellion and praised 'its bold courage in practice', identifying their slogan and claim for participatory democracy as 'the common denominator of the rebellions in the East and West', which derived, she asserted, from 'the best in the revolutionary tradition' (Arendt 1969, pp. 22-23). But once again, what was exceptionally striking to Arendt about this rebellion was what she designated as its 'moral character' (Arendt 1969, p. 23). 'Nothing, indeed, about the movement is more striking than its disinterestedness', she found (Arendt 1969, p. 23). And in a crucial formulation, Arendt indicated what the moral character of this disinterestedness

\footnotetext{
${ }^{16}$ For an excellent overview of Arendt's understanding of violence in relation to power, and how the two are 'essentially antithetical in principle', see Hutchings (2017). Also see the unsparing critique by Gines (2014) of Arendt's 'double-sided approach to violence' whereby Arendt 'presents violence uncritically in some contexts', including in The Jewish Writings, and 'hypercritically in other contexts', especially when she considers anti-colonial struggles. Patricia Owens (2009, p. 1 and especially pp. 13-33) examines how 'we also find in Arendt's work praise for the experience of war as the quintessential moment for humans to be most fully alive and political'.
} 
entailed: 'To be sure, every revolutionary movement has been led by the disinterested, who were motivated by compassion or by a passion for justice' (Arendt 1969, p. 24). Disinterested compassion and passion for justice then, as opposed to particular interests, were what Arendt cited as evidence of the 'moral character' of collective political action.

Yet, to return to the disobedients of 'Civil Disobedience', Arendt would reserve the relevance of moral imperatives to the domain of individual conscience and acts, rejecting their mobilization as justification for collective acts of disobedience. ${ }^{17}$ She was certain that

arguments raised in defense of individual conscience or individual acts, that is, moral imperatives and appeals to a 'higher law', be it secular or transcendent, are inadequate when applied to disobedience; on this level, it will not only be 'difficult' but impossible 'to keep civil disobedience from being a philosophy of subjectivity ... intensely and exclusively personal, so that any individual, for whatever reason, can disobey'. (Arendt 1970, pp. 56-57)

What was also difficult, if not impossible, then, was for Arendt to keep her own characterization of civil disobedience and 'every revolutionary movement' from becoming an intensely moral and personal 'philosophy of subjectivity' itself. Arendt attempted to overcome this difficulty by intimating that rather than 'subjective illusions' (see Enaudeau and Bonnigal-Katz 2007) common opinion and collective agreement 'objectively' grounded civil disobedience and revolutionary movements. But she did not explain in which sense the 'moral passion for justice' animating the disinterested formation of common opinion could be considered impartial or objective, nor did she elucidate how such a passion would not appeal to a 'higher law', be it secular or transcendent.

In any case, for Arendt, what the Black Power movement collectively held was not common opinion, but common interest, as if the latter did not require articulation, persuasion, consensus or agreement, and as if it could not, categorically, be driven by a disinterested passion for justice. Moreover, what the Black Power movement as an 'interest group' shared were particular interests given by a common and unchangeable 'race', while Arendt understood race, at least in this case, as 'a fact of life' (Arendt 1969, p. 76), as in 'the organic and natural facts-[of] a white or black skin—which no persuasion or power could change' (Arendt 1969, p. 76). ${ }^{18}$ Is

\footnotetext{
17 Conscience, for Arendt, was the product of an internal dialogue between me and myself and was concerned primarily with the relationship of myself to myself. It was a private, subjective, and unpolitical matter. Accordingly, as Smith (2010, p. 151) finds, 'conscientious objection is characterized by Arendt as an "unpolitical" protest, a potentially commendable, but ultimately subjective, and in a sense, self-interested action'. For an examination of Arendt's struggle with the concept of 'conscience' in her Eichmann In Jerusalem: A Report on the Banality of Evil, see Çubukçu (2015).

18 This understanding of 'race' as an organic and natural fact, which 'no persuasion or power could change' complements Arendt's (1958) assertion in The Origin of Totalitarianism that 'our political life rests on the assumption that we can produce equality through organization, because man can act in and change and build a common world, together with his equals and only with his equals. The dark background of mere givenness, the background formed by our unchangeable and unique nature, breaks into the political scene as the alien which in its all too obvious difference reminds us of the limitations of
} 
it surprising then that she would also find that 'it is always the same story: interest groups do not join the rebels' (Arendt 1969, footnote 39 on p. 23)—white rebels, let it be underscored, whose 'revolutionary idea', according Arendt, was disinterested 'moral passion' (Arendt 1969, footnote 39 on p. 23)? Nothing was of surprise here, at least not for Arendt, who also opined that it went 'against the very nature of selfinterest to be enlightened' (Arendt 1969, p. 78).

\section{II}

In 'Civil Disobedience', Arendt recognized that 'disobedience to the law, civil and criminal, has become a mass phenomenon in recent years, not only in America, but also in a great many other parts of the world' (Arendt 1970, p. 69). Yet, despite the global reach of the phenomenon, in a series of arduous moves, she offered such a justification for civil disobedience that it would have no validity outside the United States. This was the case because while certain public acts of non-violent lawbreaking could be justified as civil disobedience according to Arendt, the exceptionality of the United States as a revolutionary republic and the particularity of the 'spirit of its laws' (Arendt 1970, p. 83) served as the ground on which such acts could be justified and justified as properly American ways of breaking the law. The 'spirit' of American laws, in brief, was what would guarantee the civil-hence the non-criminal, even the necessary-character of particular acts of lawbreaking and do so only in the United States, exceptionally.

According to Arendt, not only was civil disobedience 'compatible with the spirit of American laws' (Arendt 1970, p. 99), but it was also 'primarily American in origin and substance' (Arendt 1970, p. 83). This was the case considering that:

No other country, and other language, has even a word for it, and that the American republic is the only government having at least a chance to cope with it-not, perhaps, in accordance with its statutes, but in accordance with the spirit of its laws. The United States owes it origin to the American Revolution, and this revolution carried within it a new, never fully articulated concept of law, which was the result of no theory but had been formed by the extraordinary experiences of the early colonists. (Arendt 1970, p. 83)

What then was this spirit? 'Consent', argued Arendt, 'in the sense of active support and continuing participation in all matters of public interest', was the 'spirit' of American law, its 'new concept of law' (Arendt 1970, p. 85). While such consent was 'indeed easy to denounce as mere fiction' of an original social contract between a people and its government, in the case of 'the American prerevolutionary experience, with its numerous covenants and agreements', it was 'no mere fiction' in Arendt's eyes (Arendt 1970, p. 85). In fact, Arendt argued that the signatories of

Footnote 18 (continued)

human activity — which are identical with the limitations of human equality' (Arendt 1973, p. 301), emphasis added. See also Michiel Bot (2019). 
the American Declaration of Independence were thinking in terms of the "horizontal version of the social contract' (1970, p. 86) articulated by Locke as the 'generalization and conceptualization' of specifically American experiences (Arendt 1970, p. 87).

Moreover, while 'consent-meaning that voluntary membership must be assumed for every citizen in the community' (Arendt 1970, p. 87) was, except in the case of naturalization, 'at least as open to the reproach of being a fiction as the aboriginal contract', Arendt mobilized the no less vexing concept of tacit consent to argue that such a reproach would be 'existentially and theoretically' invalid (Arendt 1970, p. 87). 'Tacit consent is not a fiction; it is inherent in the human condition' (Arendt 1970, pp. 87-88), she asserted. Every newborn came into a particular community and this 'factual situation' implied 'a kind of conformity to the rules under which the great game of the world is played in the particular group', whereby 'tacit consent [is] given in exchange for the community's tacit welcome of the new arrivals' (Arendt 1970, p. 88), she found. But even if this existential scenario were valid, a question would still remain: could such tacit consent ever be considered voluntary? In the case of the United States, at least, Arendt thought so: 'We might call it voluntary, though, when the child happens to be born into a community in which dissent is also a legal and de-facto possibility once he has grown into a man' (Arendt 1970, p. 88). And in the next sentence, she would attempt to tie, 'somehow', the possibility of dissent with the very existence of tacit consent: 'Dissent implies consent, and is the hallmark of free government; one who knows that he may dissent knows also that he somehow consents when he does not dissent' (Arendt 1970, p. 88).

Whether or not Arendt's particular account of the United States as 'a society of consent'-based on what Tocqueville called 'tacit agreement, a sort of consensus universalis ${ }^{19}$ - is convincing, it could not completely ignore one crucial fact. In Arendt's words, 'the reason [Tocqueville] could predict the future of Negroes and Indians for more than a century ahead [lied] in the simple and frightening fact that these people had never been included in the original consensus universalis of the American republic' (Arendt 1970, p. 90). In fact, not only were African Americans and Native Americans excluded from the original consensus universalis, arguably, their enslavement, slaughter, and dispossession through violent acts of settler colonialism were constitutive of the revolutionary republic that Arendt so praised. ${ }^{20}$ But in 'Civil Disobedience', Arendt did not entertain such interpretations of the violent

\footnotetext{
19 Arendt's indebtedness to Tocqueville is not appreciated enough by many commentators on 'Civil Disobedience'. For example, see Smith (2010).

${ }^{20}$ Compare Rana (2010), The Two Faces of American Freedom, for instance, with Arendt's (1963) On Revolution, where she discusses the American Revolution at length. Also see Gines's detailed account of the acknowledgement yet disavowal of racial slavery in Arendt's On Revolution. As Gines observes, 'although slavery is understood to be a crime by Arendt, it is almost simultaneously dismissed as a social question. Accordingly, the founding fathers are celebrated for focusing on political rather than social issues, even while she notes that they understood that the institution of slavery from the beginning had undermined the political principle of freedom' (2014, p. 59, emphasis added).
} 
and racist 'spirit' of American law, ${ }^{21}$ except when she critiqued the manifestation of such interpretations in the abolitionist movement and the black organizations of her time.

Thus, the 'tragedy' of the abolitionist movement was, according Arendt, that 'it could appeal only to individual conscience, and neither to the law of the land nor to the opinion of the country' (Arendt 1970, p. 90). It is telling that Arendt marked this predicament not as the constitutive 'tragedy' of the American republic-with its racist laws and public opinion that legalized and legitimized slavery-but as the grounds for criticizing the abolitionist movement's

anti-institutional bias, its abstract morality, which condemned all institutions as evil because they tolerated the evil of slavery, and which certainly did not help in promoting those elementary measures of humane reform by which in all other countries the slaves were gradually emancipated into the free society. (Arendt 1970, p. 90)

Further still, Arendt preferred to think of slavery, which she called the 'original crime', as a 'tacit exclusion from the tacit consensus' of the American nation without explaining what exactly was tacit about the bloody practice of slavery-or the mass slaughter and dispossession of Native Americans through settler colonialismwhich by definition negated consent, the alleged 'spirit' of American law (Arendt 1970, pp. 90-91).

Instead, 'consent as it is implied in the right to dissent-the spirit of American law and the quintessence of American Government', Arendt insisted, 'spells out and articulates the tacit consent given in exchange for the community's tacit welcome of new arrivals, of the inner immigration through which it constantly renews itself' (Arendt 1970, p. 88). Equating this 'general tacit consent' or consensus universalis with consent to the American constitution, moreover, Arendt was careful to argue that it did not imply consent to specific laws or specific policies, even when the latter were the result of majority decision (Arendt 1970, pp. 88-89). In any case, in the late 1960s, 'the current danger of rebellion in the United States' did not arise, to Arendt's mind, from dissent and resistance to particular laws: 'what we are confronted with is a constitutional crisis of the first order' (Arendt 1970, p. 89, emphasis added), she argued.

It was the coincidence of 'two very different factors', Arendt found, which effected this constitutional crisis:

There are the frequent challenges to the Constitution by the administration, with the consequential loss of confidence in constitutional processes by the people, that is, the withdrawal of consent; and there has come into the open, at

\footnotetext{
21 This oversight (to say the least) is consistent with Arendt's (1969) conceptual distinctions in On Violence, where 'Arendt banishes violence from politics conceptually, but fails to engage with the problem of how violence might both be, on occasion, constitutive of politics, and not contaminate it' (Frazer and Hutchings 2008, pp. 90-108, p. 102). See also Kautzer's (2019, p. 2) convincing argument that in On Violence, Arendt implicitly relies on 'a constitutive and racialized form of violence', which leaves 'legal and state violence presumed, but untheorized'.
} 
about the same time, the more radical unwillingness of certain sections of the population to recognize the consensus universalis. (Arendt 1970, p. 89)

What is remarkable in Arendt's double-formulation of these two factors is how it assigns responsibility for the constitutional crisis that she perceived. On the one hand, it was the United States' administration which Arendt found responsible for occasioning the withdrawal of consent by 'the people'. On the other hand, however, Arendt placed responsibility for the constitutional crisis squarely on the radical unwillingness of 'certain sections of the population' to recognize the consensus universalis, including 'the Negro people of America ... these people who had never been welcome' (Arendt 1970, p. 91). ${ }^{22}$ But if they had never been welcome (though such a formulation was deceptive - the enslaved were indeed welcomed by settlers for the exploitation of their labour power) along with Native Americans whose lands were appropriated through settler colonialism, Arendt failed to explain why these 'sections of the population' could or should be expected to offer consent, tacit or otherwise, to the consensus universalis, or the American constitution, at all.

Instead of reflecting sufficiently on this question that would haunt her discussion of civil disobedience in the United States, concerning contemporary 'black organizations' of her time, Arendt dismissively declared that 'quite a number of their leaders care little about the rules of nonviolence for civil disobedience and, often, just as little about the issues at stake - the Vietnam war, specific defects in our institutions-because they are in open rebellion against all of them' (Arendt 1970, p. 92). Lumping together an undifferentiated mass of organizations diverse in their political orientation and forms of action, Arendt thereby excluded from the domain of civil disobedience-whose 'rules' spelled non-violence to her mind-'black organizations' that allegedly cared not for such rules. ${ }^{23}$ Rather than granting the possibility that the open rebellion of black organizations against all institutions of a society that excluded them from its consensus universalis could be considered justified and legitimate, Arendt denied such organizations engaged in lawbreaking action the very possibility of practicing civil disobedience. What is more, since disobedience to the law could be either civil or criminal according to Arendt, she contributed to the criminalization of these black organizations. ${ }^{24}$ In that, she was keeping with an American tradition in fact.

'It is the people's support that lends power to the institutions of a country, and this support is but the continuation of the consent that brought the laws into existence to begin with', Arendt wrote (1969, p. 41), in the midst of the constitutional

\footnotetext{
22 On the same page, Arendt asserts that "we need not be surprised that the present belated attempts to welcome the Negro population explicitly into the otherwise tacit consensus universalis of the nation are not trusted'. Interpreting this remark to be 'insightful', Gines nevertheless observes how the 'insight is again undermined by her myopic and monolithic representation of Black people as violent and having misplaced priorities' in the sentences that follow (2014, p. 121).

23 Rather than an accurate historical description, such statements by Arendt reflect her 'dismissive assumptions about where Black leaders' "cares" do and do not lie' (Gines 2014, p. 122).

24 As Angela Davis and many critical race theorists have argued, crime is 'one of the masquerades behind which "race", with all its menacing ideological complexity, mobilizes old public fears and creates new ones' (1997, pp. 256-279, p. 266).
} 
crisis, nay, the revolutionary situation fraught with 'the danger of rebellion' (Arendt 1970 , p. 89) that she perceived. She thus opposed a tradition of thought-including Marx and Benjamin - that saw in violence, not consent, the original force that brings laws into existence. ${ }^{25}$ At once, she wove together concepts-support, consent, opinion, power-to contest the traditional centrality accorded to violence in understanding that which compels 'obedience' to the law. Employing an analogy between obeying the law and playing 'a game with valid rules', Arendt wrote:

For the point of these rules is not that I submit to them voluntarily or recognize theoretically their validity, but that in practice I cannot enter the game unless I conform; my motive for acceptance is my wish to play, and since men exist only in the plural, my wish to play is identical with my wish to live. Every man is born into a community with pre-existing rules which he 'obeys' first of all because there is no other way for him to enter the great game of the world. (Arendt 1969, Appendix XI to p. 41, n. 62, on p. 97)

By analogy, Arendt suggested, one obeys the law because one wishes to live in the plural, where power arises from the common opinion of and consent granted by a given number of people and where the strength of opinion, like that of consent, depends 'on the number of those with whom it is associated' (Arendt 1970, p. 68). ${ }^{26}$

Arendt further claimed that if 'I may wish to change the rules of the game, as the revolutionary does, or to make an exception for myself, as the criminal does', such wishes would entail—even when they involved lawbreaking action-not the denial of the law on principle, but disobedience to it (Arendt 1969, Appendix XI to p. 41, n. 62, on p. 97). To her mind, to deny the rules of the game, or the law, on principle meant "no mere "disobedience", but the refusal to enter human community' (Arendt 1969, Appendix XI to p. 41, n. 62, on p. 97) as such. She did not go so far as to suggest that 'certain sections of the population' in the United States who demonstrated a radical unwillingness to recognize the consensus universalis thereby refused to enter the human community. Arendt did argue, however, that the constitutional crisis in the United States was due to the radical refusal of 'certain sections of the population' to recognize the American constitution-a law whose 'spirit' was not consent, pace Arendt, but violence and racism in their eyes.

Opinion formation involved discursive, representative thinking: validity in matters of opinion 'depends on free agreement and consent; they are arrived at by discursive, representative thinking; and they are communicated by means of persuasion and dissuasion', Arendt indeed argued (1993b, p. 247). Nevertheless, she did not identify her criteria for designating as verbal violence certain opinions expressed by black students (Arendt 1969, p. 19), which appeared not as opinions to her mind, but as self-interested 'Negro demands' that were 'clearly silly and outrageous' (Arendt 1969, p. 19). Black violence and 'Negro demands' went hand in hand for

\footnotetext{
${ }^{25}$ For a brilliant exposition of the law-making capacity of violence, see Walter Benjamin (1921), 'Critique of Violence'.

${ }^{26}$ While power could employ violence, according to Arendt, it could not arise from violence-power depends on numbers, and violence on implements.
} 
Hannah Arendt, who insisted that neither was legitimate. In her attempt to evaluate 'the citizen's moral relation to the law in a society of consent' (Arendt 1970, p. 51), Arendt took it for granted that the United States was one, while she excluded from the domain of civil disobedience black organizations that wished to change the rules of the consent-giving-game through lawbreaking action, which she condemned as 'black violence' (Arendt 1969, p. 19).

\section{III}

Towards a conclusion, I would like to reflect on the observation by an Arendtian scholar that Arendt was 'strongly opposed to organizing political and legal institutions, much less understanding the history of her time, in terms of race', and that for her, 'it was disastrous to have a polity in which some citizens had more rights, more privileges and immunities, than others did, whatever their race and ethnicity' (King 2010, p. 133). To my mind, such a philosophical and political taste for what Angela Davis critiques as 'race-blindness' (Davis 1997) constitutes an essential reason why in the 1960s, Arendt was 'scathing about what she felt were racist political, educational, and cultural demands of Black Power advocates' (King 2010, p. 133, emphasis added). ${ }^{27}$

Arendt's scathing denunciation of the alleged racism of the Black Power movement, coupled with her 'diatribe against affirmative action' (see Jay 1997, p. 350) could suffice to place her thought within conservative (at best) or racist (at worst) understandings of what racism and antiracism entailed in the context of the United States. In December 1968, Arendt wrote:

Today the situation is quite clear. Negroes demand their own curriculum without the exacting standards of white society and, at the same time, they demand admission in accordance with their percentage in the population at large, regardless of standards. In other words they actually want to take over and adjust standards to their own level. This is a much greater threat to our institutions of higher learning than the student riots. ${ }^{28}$

The least that could be said about Arendt's judgements concerning such 'Negro demands' is that 'they do little to suggest that Arendt's mentality was very enlarged when it came to the issue of race in America' (see Jay 1997, footnote 12). But how large could her 'enlarged mentality' be-even had she pushed it to its limits—-given that the decided absence of other standpoints was a constitutive element of this mentality?

Explaining the framework of enlarged mentality for the New Yorker in 1967, Arendt wrote: 'I form an opinion by considering a given issue from different

\footnotetext{
27 In fact, Arendt (1969, p. 77) finds that it is 'Black racism' which has the potential to provoke 'a really violent white backlash'.

28 Emphasis added. See Hannah Arendt's letter to Mary McCarthy, 21 December 1968, quoted in Martin Jay (1997, p. 350, footnote 12). For the rest of this paragraph see Brightman (1995, pp. 230-231).
} 
viewpoints, by making present to my mind the standpoints of those who are absent; that is, I represent them. This process of representation does not blindly adopt the actual views of those who stand somewhere else. ... I can make myself the representative of everybody else', she asserted (Arendt 1993b, pp. 241-242, emphasis added). But could she? Could anybody? ${ }^{29}$ If the answer is no, then it is difficult not to disagree with Arendt's entire Kantian framework of representative thinking and judgement-including its impossible demands for impartiality and disinterestedness - which were 'flawed' and inhibited her understanding of 'the Negro problem' (Gines 2014, p. 2). In Arendt's case, this enlarged mentality led to a judgement about what is best for the common good in accordance with the particular standards of what she did not hesitate to call 'white society', ${ }^{30}$ unless of course, she thought these standards were universally valid—valid not only for assessing achievement in the United States but across the world, not only for 'the humanities' but also for 'humanity'. 31

Arendt's strong rejection of affirmative action and the Black Power movement can be interpreted as an early articulation of contemporary-and categoricalobjections to 'identity politics' on the grounds that it constitutes 'reverse racism', or else, a divisive form of politics. In this reading, Arendt would be prescient in having anticipated what Angela Davis diagnosed as the 'post-Civil Rights era' some 30 years after 1968, an era in which 'race itself becomes an increasingly proscribed subject':

In the dominant political discourse [race] is no longer acknowledged as a pervasive structural phenomenon, requiring the continuation of such strategies as affirmative action, but rather is represented primarily as a complex of prejudicial attitudes, which carry equal weight across all racial boundaries. Black leadership is thus often discredited and the identification of race as a public, political issue itself called into question through the invocation of, and application of the epithet 'black racist' ... (Davis 1997, p. 264)

Perhaps Arendt did not so much anticipate as she did participate in the very arrival of such a post-civil rights era in the United States - after all, she was already writing publicly about 'Black racism' in 1969 (Arendt 1969, p. 77). But are we still in this

\footnotetext{
29 It is important to recall here that impartiality achieved through representative thinking is, for Arendt, 'the root of so-called objectivity, this curious passion unknown outside Western civilization, for intellectual integrity at any price'.

30 See Hannah Arendt's letter to Mary McCarthy, 21 December 1968, quoted in Martin Jay (1997, p. 350 , footnote 12).

31 Arendt (1993c, p. 192) had a 'conservative' understanding of education and its relationship to 'culture', which is beyond the scope of this article to examine. Allow me to note here her view that 'conservatism, in the sense of conservation, is of the essence of educational activity, whose task is always to cherish and protect something'. As for 'culture', I should note the powerful argument by political theorist Jimmy Casas Klausen that Arendt's understanding of 'culture', developed in her Origins of Totalitarianism and later work, is grounded on 'antiprimitivist' premises that order humanity hierarchically. However, Klausen does not seriously consider how ideas of 'culture' can operate as proxies for 'race' and as alibis for racism. See Klausen (2010, pp. 394-423). Also see the response and defence of Arendt by Gundogdu (2011, pp. 661-667) and Klausen's (2011, pp. 668-673) response to Gundogdu.
} 
era, or not yet? In either case, is it not conceivable that Arendt would have seen in 'All Lives Matter' an antiracist opinion today, which assumes force-lawbreaking or not-against 'Black Lives Matter'?

I have made the argument that Arendt's thoughts about the ostensibly non-racial subjects of civil disobedience and lawbreaking were underwritten by racial, when not racist, modes of thinking. This should hardly be surprising, unless one would expect an exception in Arendt's case, an exception from the white supremacism that engulfed political life in the United States long before and long after 1968. And why should Arendt have been immune from the racism of her time-both implicit and explicit-which permeated political thought across 'Western civilization', and whose supremacy she proudly expounded ${ }^{32}$ The answer lies in the vitality of antiracist thought and action in her own day, which she took pains to exclude from the zone of civil disobedience by naming them unpolitical manifestations of conscience, self-interest, and violence. Here, Martin Luther King shall speak, to whose name and 'conscience' Arendt only once refers in her reflections on civil disobedience. 'Our nation was born in genocide when it embraced the doctrine that the original American, the Indian, was an inferior race. Even before there were large numbers of Negroes on our shores, the scar of racial hatred had already disfigured colonial society. From the sixteenth century forward, blood flowed in battles of racial supremacy. We are perhaps the only nation which tried as a matter of national policy to wipe out its indigenous population. Moreover, we elevated that tragic experience into a noble crusade. Indeed, even today we have not permitted ourselves to reject or to feel remorse for this shameful episode. Our literature, our films, our drama, our folklore all exalt it' (King 1963). ${ }^{33}$ Today, as we think through our own emergencies across the world, our own obedience and disobedience to the law, now is as good a time as any to think through whom and what we hasten or hesitate to call 'racist' and 'violent' — and why.

Acknowledgements Many friends and colleagues generously offered comments on this essay. In particular, I would like to thank Gil Anidjar, Talal Asad, Yavuz Aykan, Nathaniel Berman, Partha Chatterjee, Siddhartha Deb, Tobias Kelly, Balam Kenter, Biju Mathew, Peter Mcisaac, Esra Özyürek, Sayres Rudy, Sara Salem, Anita Starosta, Geoff Waite, and fellow travellers Vasuki Nesiah and Vidya Kumar. Earlier versions of the essay also benefited from feedback at the 'Countering Authoritarianism Workshop' at the Monash University Center in Prato; 'Social and Political Philosophy Workshop' at Fordham University; 'Birkbeck Law School Seminar Series' at Birkbeck, University of London; 'Institute for Global Law and Policy Speaker Series' at the Harvard Law School; and the Fung Global Fellows Program at Princeton University, where it was partially funded.

\footnotetext{
32 Note how Richard H. King claims that Arendt never 'elevate[d] Western thought and culture above the other great world cultures' (2010, p. 133). Nevertheless, Butler (2007) is clear about the supremacism which inflected Arendt's thought: 'A presumption about the cultural superiority of Europe pervades much of her later writings too, and is clearest in her intemperate criticisms of Fanon, her debunking of the teaching of Swahili at Berkeley, and her dismissal of the black power movement in the 1960s. She clearly does not have racial minorities in mind when she thinks about those who suffer statelessness and dispossession. She appears to have separated the nation from the nation-state, but to the degree that the conception of "minorities" is restricted to national minorities, "nation" not only eclipses "race" as a category, but renders race unthinkable'.

33 I thank Talal Asad for this reference.
} 
Funding The essay was partially funded by the Fung Global Fellows Program at Princeton University.

\section{Compliance with Ethical Standards}

Conflict of interest The authors declare that they have no conflict of interest.

Open Access This article is licensed under a Creative Commons Attribution 4.0 International License, which permits use, sharing, adaptation, distribution and reproduction in any medium or format, as long as you give appropriate credit to the original author(s) and the source, provide a link to the Creative Commons licence, and indicate if changes were made. The images or other third party material in this article are included in the article's Creative Commons licence, unless indicated otherwise in a credit line to the material. If material is not included in the article's Creative Commons licence and your intended use is not permitted by statutory regulation or exceeds the permitted use, you will need to obtain permission directly from the copyright holder. To view a copy of this licence, visit http://creativecommons.org/licenses/by/4.0/.

\section{References}

Arendt, Hannah. 1963. On revolution. New York: Viking Press.

Arendt, Hannah. 1969. On violence. New York: Harcourt.

Arendt, Hannah. 1970. Civil disobedience. In Crises of the republic, 49-103. New York: Houghton Mifflin Harcourt Publishing.

Arendt, Hannah. 1973 [1958]. The origins of totalitarianism. New York: Harcourt.

Arendt, Hannah. 1993a. Truth and politics. In Between past and future: Eight exercises in political thought, 223-260. New York: Penguin Books.

Arendt, Hannah. 1993b. The crisis in culture: Its social and its political significance. In Between past and future: Eight exercises in political thought, 194-222. New York: Penguin Books.

Arendt, Hannah. 1993c. The crisis in education. In Between past and future: Eight exercises in political thought, 170-193. New York: Penguin Books.

Arendt, Hannah. 1994. Eichmann in Jerusalem: A report on the banality of evil. New York, NY: Penguin Books.

Arsenault, Raymond. 2006. Freedom riders: 1961 and the struggle for racial justice. Oxford: Oxford University Press.

Benjamin, Walter. 1921. Critique of violence. In Walter Benjamin: Selected writings, Volume 1: 19131926, ed. M. Bullock and M.J. Jennings. Cambridge, MA: Harvard University Press.

Berkowitz, Roger. 2018. Citizenship and civil disobedience: Reflections of civil war and civil disobedience. 14 October. The Hannah Arendt Center. https://medium.com/@arendt_center/citizenship-andcivil-disobedience-reflections-on-civil-war-and-civil-disobedience-4481e7a447fa. Accessed 1 July 2020.

Bot, Michiel. 2019. The conditions of 'savages'? Statelessness, politics, and race in Hannah Arendt's The Origins of Totalitarianism. The Statelessness and Citizenship Review 1 (2): 195-213.

Brightman, Cary (ed.). 1995. Between friends: The correspondence of Hannah Arendt and Mary McCarthy, 1949-1975. New York: Harcourt Brace Jovanovich.

Butler, Judith. 2007. I merely belong to them. London Review of Books 29 (9): 26-28.

Calhoun, Craig, and John McGowan, ed. 1997. Introduction. In Hannah Arendt and the meaning of politics, 1-24. Minneapolis: University of Minnesota Press.

Caver, Martin. 2019. A different price for the ticket: Hannah Arendt and James Baldwin on love and politics. Polity 51(1): 35-61. https://doi.org/10.1086/700614. Accessed 1 July 2020.

Creegan, James. 2016. The rebel who came in from the cold: The tainted career of Bayard Rustin. Portside. 17 March. https://portside.org/2016-03-17/rebel-who-came-cold-tainted-career-bayard-rustin. Accessed 1 July 2020.

Critical Philosophy of Race. 2013. Critical Philosophy of Race 1(1), Special issue on Critical philosophy of race beyond the black/white binary.

Çubukçu, Ayça. 2015. On the exception of Hannah Arendt. Law, Culture and the Humanities 15(3): 684704. https://doi.org/10.1177/1743872115588442. Accessed 1 July 2020. 
Çubukçu, Ayça. 2017. Thinking against humanity. London Review of International Law 5(2): 251-267. https://doi.org/10.1093//ril/lrx006. Accessed 1 July 2020.

Davis, Angela Y. 1997. Race and criminalization: Black Americans and the punishment industry. In The House that race built, ed. Wahneema Lubiano, 264-279. New York: Vintage Books.

Delmas, Candice. 2018. A duty to resist: When disobedience should be uncivil. Oxford: Oxford University Press.

Dossa, Shiraz. 1980. Human status and politics: Hannah Arendt on the Holocaust. Canadian Journal of Political Science 13 (2): 309-323.

Enaudeau, Corinne, and Dorothée Bonnigal-Katz. 2007. Hannah Arendt: Politics, opinion, truth. Social Research 74 (4): 1029-1044.

Frazer, Elizabeth, and Kimberly Hutchings. 2008. On politics and violence: Arendt contra Fanon. Contemporary Political Theory 7 (1): 90-108.

Gines, Kathryn T. 2014. Hannah Arendt and the negro question. Indianapolis: Indiana University Press.

Gundogdu, Ayten. 2011. Arendt on culture and imperialism: Response to Klausen. Political Theory 39 (5): 661-667.

Hughes, Graham. 1968. Civil disobedience and the political question doctrine. New York University Law Review 43 (1): 1-19.

Hutchings, Kimberly. 2017. Hannah Arendt. In Histories of violence: Post-war critical thought, ed. Brad Evans and Terrell Carver, 33. London: Zed Books.

Jay, Martin. 1997. Afterword. In Hannah Arendt and the meaning of politics, ed. Craig Calhoun and John McGowan, 338-350. Minneapolis: University of Minnesota Press.

Kalyvas, Andreas. 2008. Democracy and the politics of the extraordinary: Max Weber, Carl Schmitt, and Hannah Arendt. Cambridge: Cambridge University Press. https://doi.org/10.1017/CBO9780511 755842. Accessed 1 July 2020.

Kautzer, Chad. 2019. Political violence and race: A critique of Hannah Arendt. CLCWeb: Comparative Literature and Culture 21(3): 8. https://docs.lib.purdue.edu/clcweb/vol21/iss3/8/ Accessed 1 July 2020.

King, Martin Luther. 1963. Why we can't wait. New York: New American Library.

King, Richard H. 2010. On race and culture: Hannah Arendt and her contemporaries. In Politics in dark times: Encounters with Hannah Arendt, ed. Seyla Benhabib, 113-134. Cambridge: Cambridge University Press.

Klausen, Jimmy Casas. 2010. Hannah Arendt's antiprimitivism. Political Theory 38 (3): 394-423.

Klausen, Jimmy Casas. 2011. Reply to Gundogdu. Political Theory 39 (5): 668-673.

Losurdo, Domenico. 2004. Towards a critique of the category of totalitarianism. Historical materialism 12(2): 25-55. https://doi.org/10.1163/1569206041551663. Accessed 1 July 2020.

Marotti, William. 2009. Japan 1968: The performance of violence and the theater of protest. The American Historical Review 114 (1): 97-135.

Martel, James. 2011. The ambivalent anarchism of Hannah Arendt. In How not to be governed: Readings and interpretations from a critical anarchist Left, ed. Jimmy Casas Klausen and James Martel, 143-157. Lanham: Lexington Books.

McGowan, John. 1998. Hannah Arendt: An introduction. Minneapolis: University of Minnesota Press.

Norton, Anne. 1995. Heart of darkness: Africa and African Americans in the writing of Hannah Arendt. In Feminist interpretations of Hannah Arendt, ed. Bonnie Honig. University Park: Pennsylvania State University Press.

Owens, Patricia. 2009. Between war and politics: International relations and the thought of Hannah Arendt. Oxford: Oxford University Press.

Passerin d'Entrèves, Maurizio. 1994. The political philosophy of Hannah Arendt. New York: Routledge.

Passerin d'Entrèves, Maurizio. 2019. Hannah Arendt. In Stanford encyclopedia of philosophy, ed. Edward N. Zalta. Stanford CA: Stanford University.

Rana, Aziz. 2010. The two faces of American freedom. Cambridge: Harvard University Press.

Smith, William. 2010. Reclaiming the revolutionary spirit: Arendt on civil disobedience. European Journal of Political Theory 9 (2): 149-166.

Thiranagama, Sharika, Tobias Kelly, and Carlos Forment. 2018. Introduction: Whose civility? Anthropological Theory 18(2-3), 153-174. https://doi.org/10.1177/1463499618780870.

Publisher's Note Springer Nature remains neutral with regard to jurisdictional claims in published maps and institutional affiliations. 